\title{
Characterization and screening of antimicrobial activity of Micromonospora strains from Thai soils
}

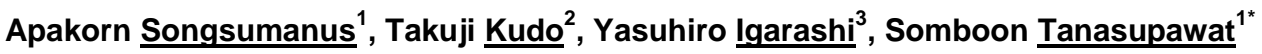 \\ ${ }^{1}$ Department of Biochemistry and Microbiology, Faculty of Pharmaceutical Sciences, \\ Chulalongkorn University, Bangkok 10330, Thailand. \\ ${ }^{2}$ Japan Collection of Microorganisms, RIKEN BioResource Center, 3-1-1 Koyadai, Tsukuba, Ibaraki 305-0074, Japan. \\ ${ }^{3}$ Biotechnology Research Center, Toyama Prefectural University, 5180 Kurokawa, Kosugi, Toyama 9390398 , Japan. \\ Email: Somboon.T@chula.ac.th
}

Received 11 March 2013; Received in revised form 29 March 2013; Accepted 11 April 2013

\begin{abstract}
Aims: Rare actinomycete strains were isolated from mountain soils and island soil collected in Thailand. They were screened for antimicrobial activity and characterized for their secondary metabolites.

Methodology and results: The strains were isolated by the standard dilution technique using starch casein nitrate agar. They were identified and characterized based on the phenotypic, chemotaxonomic and genotypic characteristics. The chemotaxonomic characteristics of ten isolates coincided with those of the genus Micromonospora. On the basis of phylogenetic analysis using 16S rRNA gene sequences and DNA-DNA relatedness, they were divided into 6 Groups, ASC19-2-1 (Group A) was identified as Micromonospora marina; AL8-8 and AL10-3 (Group B) were M. aurantiaca; AL75 (Group C) was M. chalcea; AL3-16 and AL9-20 (Group D) were identified as M. chokoriensis; AL9-13 and AL9-22 (Group E) were M. tulbaghiae; and AL1-15-2 and AL1-16B (Group F) were M. chersina. On the primary screening, only the isolate AL7-5 (Group C) could inhibit Kocuria rhizophila ATCC 9341. This isolate produced rakicidin when cultivated on A3M, A11M and A16 media and produced compound BU4664L only on A16 medium.

Conclusion, significance and impact of study: The isolation and characterization of the rare actinomycetes from Thai soils will be useful for the taxonomic study and for the discovery of bioactive metabolites that are active against microorganisms.
\end{abstract}

Keywords: Antimicrobial activity, Micromonospora, rare actinomycetes, secondary metabolites, Thai soils

\section{INTRODUCTION}

Micromonospora is the type genus of the family Micromonosporaceae. The members of this family now contains several genera, including the genera Micromonospora, Actinoplanes, Dactylosporangium and Pilimelia (Goodfellow et al., 1990). Micromonospora strains have distinct morphological characteristics in that they produce single spores on the substrate mycelium and lack aerial mycelium. The genus Micromonospora is well classified on the basis of chemotaxonomic characteristics, gyrB and 16S rRNA gene sequence analyses including DNA-DNA relatedness (Kawamoto, 1989; Koch et al., 1996; Kasai et al., 2000). Micromonospora strains are distributed widely in different environments such as in soils, water, sandstone, mangrove sediment and root nodules (Luedemann and Brodsky, 1964; Kawamoto, 1989; Hirsch et al., 2004; Ara and Kudo, 2007; Garcia et al., 2010; Songsumanus et al., 2011; Wang et al., 2011).

Micromonospora strains produce many kinds of antibiotics such as gentamicin, micromonosporin, megalomicin, mutamicin, fortimicin, sagamicin, verdamicin, dapiramicin, clostomicin, mycinamicin, dynemicin, macquarimicin, holomicin, quinolidomicins, arisostatins A and B and anthraquinones (Glasby, 1993; Berdy, 2005; Igarashi et al., 2000; 2007; Omura, 2008). During an investigation of the biodiversity and antimicrobial activity screening of actinomycetes in mountain soil and island soil in Thailand, nine isolates from the genus Micromonospora were identified and characterized based on their phenotypic, chemotaxonomic and genotypic characteristics.

\section{MATERIALS AND METHODS}

\section{Isolation methods}

The actinomycete strains were isolated from mountain soils in Phukradung, Loei province, the North Eastern part of Thailand and from Nok Island, Chonburi province, the Eastern part of Thailand. The actinomycete strains were isolated by using wet heat at $70{ }^{\circ} \mathrm{C}$ for $15 \mathrm{~min}$ and the 
standard dilution technique on starch casein nitrate agar (Tanasupawat et al., 2010) supplemented with nystatin $(50 \mathrm{mg} / \mathrm{L}$ )and nalidixic acid $(20 \mathrm{mg} / \mathrm{L})$. The plates were incubated at $30{ }^{\circ} \mathrm{C}$ for 14 days and then a single colony was transferred and purified on yeast extract-malt extract agar (International Streptomyces Project, ISP medium no. 2) as described by Shirling and Gottlieb (1966). The $\mathrm{pH}$ of soil samples was determined using the dried soil samples that were dried under room temperature for 7 days. One gram of dried soil was put into the test tubes containing $2.5 \mathrm{~mL}$ of distilled water and shaken for 2 to $3 \mathrm{sec}$ before taking the $\mathrm{pH}$ reading.

\section{Identification and characterization methods}

\section{Phenotypic characterization}

The cell morphology was observed by scanning electron microscopy. The phenotypic properties were examined using several standard methods (Williams and Cross, 1971; Gordon et al., 1974; Arai, 1975). For determining the cultural characteristics, the isolates were grown on ISP 2 agar plates at $30{ }^{\circ} \mathrm{C}$ for 14 days (Shirling and Gottlieb, 1966) after that the colony colours were determined using the NBS/IBCC Colour System. Temperature, $\mathrm{pH}$ and $\mathrm{NaCl}$ concentration ranges for the growth of isolates were tested on ISP 2 agar at $30{ }^{\circ} \mathrm{C}$ for 14 days. ISP 9 agar supplemented with $1 \%$ sole carbon source was used to determine their carbon utilization.

\section{Chemotaxonomic characterization}

For chemotaxonomy, freeze-dried cells were collected from 4-day-old cultures grown in ISP 2 broth on a rotary shaker at $30^{\circ} \mathrm{C}$. The cell wall peptidoglycan was prepared by the method of Kawamoto et al. (1981). The isomer of diaminopimelic acid was determined by the TLC method of Staneck and Roberts (1974). The $N$-acyl group of the muramic acid in the peptidoglycan was analysed by spectrophotometer using the method of Uchida and Aida (1984). Isoprenoid quinones were extracted by the method of Collins et al. (1977) and then analysed by HPLC equipped with a Cosmosil 5C18 column (4.6 by 150 $\mathrm{mm}$, Nacalai Tesque, Kyoto, Japan). Whole cell sugars were analysed according to Mikami and Ishida (1983). Methyl esters of cellular fatty acids were prepared from cells grown on ISP 2 (Yeast extract-malt extract agar), and identified by GLC according to the Microbial Identification System (MIDI) (Sasser, 1990; Kämpfer and Kroppenstedt, 1996).

\section{Genotypic characterization}

Chromosomal DNA was extracted from cells grown in ISP 2 broth supplemented with $0.1 \%$ glycine (Yamada and Komagata, 1970; Tamaoka, 1994). The G + C content of the DNA was determined by HPLC (Tamaoka, 1994). DNA-DNA relatedness was determined according to Ezaki et al. (1989). The 16S rRNA gene was amplified by using primers $27 \mathrm{~F}$ and $1492 \mathrm{R}$ as described by Nakajima et al.
(1999). The 16S rRNA gene sequence was multialigned with selected sequences obtained from the GenBank/EMBL/DDBJ databases by the CLUSTAL_X version 1.83 program (Thompson et al., 1997). The aligned sequences were manually edited before constructing the phylogenetic tree by the neighbourjoining (Saitou and Nei, 1987). The branches confidence values of the phylogenetic tree were examined by bootstrap analysis (Felsenstein, 1985) based on 1,000 resamplings. Gaps and ambiguous nucleotides were deleted manually before analysing the similarity values by CLUSTAL_X (Thompson et al., 1997). Screening of antimicrobial activities and preliminary
characterization of secondary metabolites

The isolates were streaked along the diameter of ISP 2 agar medium and cultivated for 14 days at $30^{\circ} \mathrm{C}$. The test microorganisms were then streaked out perpendicular to the selected isolates about $3 \mathrm{~mm}$ apart from them and incubated at $30^{\circ} \mathrm{C}$ for 1 day. The tested microorganisms used in this study were Escherichia coli ATCC 25922, Bacillus subtilis ATCC 6633, Staphylococcus aureus ATCC 25923, Kocuria rhizophila ATCC 9341, Pseudomonas aeruginosa ATCC 27853, and Candida albicans ATCC 10231. The clear zone was present if the isolates inhibited the growth of test microorganisms.

The selected actinomycete culture was transferred to the $\mathrm{Bn}-2$ agar slant consisting (w/v) of $0.5 \%$ glucose, $0.5 \%$ soluble starch, $0.1 \%$ meat extract, $0.1 \%$ yeast extract, $0.2 \% \mathrm{NZ}$-case, $0.2 \% \mathrm{NaCl}, 0.1 \% \mathrm{CaCO}_{3}, 1.5 \%$ agar $(\mathrm{pH}$ 7.0) and incubated at $30^{\circ} \mathrm{C}$ for 3-4 days. A loop-full of a mature slant culture was inoculated into $100 \mathrm{~mL}$ of the seed medium (V-22) consisting of soluble starch $1 \%$, glucose $0.5 \%$, NZ-case $0.3 \%$, yeast extract $0.2 \%$, tryptone $0.5 \%, \mathrm{~K}_{2} \mathrm{HPO}_{4} 0.1 \%, \mathrm{MgSO}_{4} .7 \mathrm{H}_{2} \mathrm{O} 0.05 \%$ and $\mathrm{CaCO}_{3}$ $0.3 \%(\mathrm{pH} 7.0)$ and incubated at $30{ }^{\circ} \mathrm{C}$ for $3-4$ days on a rotary shaker $(200 \mathrm{rpm})$. Three milliliter aliquots of the seed cultures were transferred into $500 \mathrm{~mL}$ flasks containing $100 \mathrm{~mL}$ of 3 kinds of media such as A3M: $0.5 \%$ glucose, $2 \%$ glycerol, $2 \%$ soluble starch, $1.5 \%$ Pharmamedia, $0.3 \%$ yeast extract, $1 \%$ Diaion HP-20 (Mitsubishi Chemical Co.), pH 7.0; A11M: 0.2\% glucose, $2.5 \%$ soluble starch, $0.5 \%$ yeast extract, $0.5 \%$ polypeptone, $0.5 \% \mathrm{NZ}$-amine, $0.3 \% \mathrm{CaCO}_{3}, 1 \%$ Diaion HP-20, pH 7.0; and A16: $0.2 \%$ glucose, $1.5 \%$ Pharmamedia, $0.3 \% \mathrm{CaCO}_{3}, 1 \%$ Diaion HP-20, $\mathrm{pH} 7.0$. Fermentation was carried out for $5-6$ days at $30{ }^{\circ} \mathrm{C}$ on a rotary shaker (200 rpm). The culture broth was added with $100 \mathrm{~mL}$ of 1 -butanol to the flask and shaken for $2 \mathrm{~h}$. Mycelia were removed by centrifugation at $6,000 \mathrm{rpm}$ at 4 ${ }^{\circ} \mathrm{C}$ for $6 \mathrm{~min}$. One milliliter of supernatant was transferred to a small vial and evaporated until it dried. The extract was dissolved with $100 \mu \mathrm{L}$ of DMSO, filtrated, and then analysed by HPLC-UV. The retention time and UV spectra of the peaks were compared by using the in-house database (Biotechnology Research Center, Toyama Prefectural University) containing about 500 reference compounds of microbial origins. 


\section{RESULTS AND DISCUSSION}

\section{Identification and characterization of the isolates}

Ten actinomycetes isolates, AL1-15-2, AL1-16B, AL3-16, AL7-5, AL8-8, AL9-13, AL9-20, AL9-22 and AL10-3 from mountain soils in Phukradung, Loei province, the north eastern part of Thailand and isolate ASC19-2-1 from Nok Island, Chonburi province eastern part of Thailand were isolated (Table 1). The $\mathrm{pH}$ of soil samples were in the range of 5.01-9.66. All isolates contained meso-DAP (diaminopimelic acid) and $N$-glycolyl muramic acid in the peptidoglycan. The whole cell sugars of all isolates were ribose, mannose, galactose, xylose and glucose [pattern $D$ of Lechevalier and Lechevalier (1970)]. The chemotaxonomic characteristics of these isolates coincided with those of the genus Micromonospora (Kawamoto, 1989). On the basis of 16S rRNA gene sequence and phylogenetic tree analyses (Figure 1), they were divided into 6 Groups as described below.

Group A contained isolate ASC19-2-1 which produced brownish gray vegetative mycelium, welldeveloped and singly rough spores on substrate hyphae on ISP 2 agar plate (Figure 2 and Table 2). The isolate grew on 1.5 to $5 \% \mathrm{NaCl}$, at pH 5 to 8 and at 15 to $40{ }^{\circ} \mathrm{C}$. It utilized L-arabinose, cellobiose, galactose, D-glucose, glycerol, salicin, and did weakly for D-fructose, D- lactose, sucrose and D-xylose. Milk peptonization, coagulation, gelatin liquefaction and starch hydrolysis of isolate were positive but nitrate reduction was negative and other characteristics were shown in Table 3. Major menaquinones were MK-9 $\left(\mathrm{H}_{4}\right) \quad(10.1 \%), \quad \mathrm{MK}-10\left(\mathrm{H}_{4}\right)$ $(65.0 \%)$, MK-10 $\left(\mathrm{H}_{6}\right) \quad(13.1 \%)$, and $\mathrm{MK}-10\left(\mathrm{H}_{8}\right)(1.1 \%)$. Major cellular fatty acids of isolate were iso- $\mathrm{C}_{16: 0}(20.1 \%)$, iso- $\mathrm{C}_{15: 0}(18.5 \%)$, anteiso- $\mathrm{C}_{17: 0}(13.2 \%)$, iso- $\mathrm{C}_{17: 0}(10.0 \%)$, iso- $\mathrm{C}_{17: 1 \omega 9 \mathrm{c}}(8.3 \%)$, and $\mathrm{C}_{17: 1 \omega 8 \mathrm{c}}(6.4 \%)$ (Table 4). The $16 \mathrm{~S}$ rRNA gene sequence and phylogenetic tree analysis
(Figure 1) showed that isolate ASC19-2-1 (1493 nt) was closely related to $M$. marina JCM $12870^{\dagger}$ (99.7\%), $M$. aurantiaca JCM $10878^{\top}$ (99.4\%), M. chalcea JCM $3031^{\top}$ $(99.2 \%)$, and $M$. coxensis JCM $13248^{\top}(99.1 \%)$. DNADNA relatedness between isolate ASC19-2-1 and closely related species, M. marina $\mathrm{JCM} 12870^{\top}$ was $83.3 \%$. Therefore, isolate ASC19-2-1 was identified as M. marina (Wayne et al., 1987; Tanasupawat et al., 2010).

Group B contained 2 isolates, AL8-8 and AL10-3. They produced brownish black vegetative mycelium, welldeveloped and singly smooth spores on substrate hyphae on ISP 2 agar plate (Figure 2 and Table 2). They grew on 1.5 to $4 \% \mathrm{NaCl}$ and weakly at $5 \% \mathrm{NaCl}$, at pH 6 to 8 and at 20 to $40{ }^{\circ} \mathrm{C}$ but grew weakly at $15{ }^{\circ} \mathrm{C}$. The isolates utilized L-arabinose, cellobiose, D-fructose, D-galactose, D-glucose, glycerol, inositol, raffinose, sucrose and Dxylose. The reactions of milk peptonization, gelatin liquefaction, starch hydrolysis, nitrate reduction were positive (Table 3 ). The isolates, AL8-8 and AL10-3 contained major menaquinones, MK- $9\left(\mathrm{H}_{4}\right)(7.5,10.7 \%)$, MK-9 $\left(\mathrm{H}_{6}\right)(7.6,16.7 \%)$, MK-9 $\left(\mathrm{H}_{8}\right)(2.2,4.9 \%), \mathrm{MK}-10\left(\mathrm{H}_{4}\right)$ $(27.2,17.6 \%)$, MK-10 $\left(\mathrm{H}_{6}\right)(26.4,33.3 \%)$, and MK-10 $\left(\mathrm{H}_{8}\right)$ $(15.0,13.5 \%)$. The major cellular fatty acids of isolate AL8-8 were iso- $\mathrm{C}_{15: 0}(6.4 \%)$, iso- $\mathrm{C}_{16: 0}(42.5 \%)$, iso- $\mathrm{C}_{17: 0}$ (4.1\%), anteiso- $\mathrm{C}_{17: 0}(11.4 \%)$, iso- $\mathrm{C}_{17: 1 \omega 9 \mathrm{c}}(6.2 \%), \mathrm{C}_{18: 1 \omega 9 \mathrm{c}}$ (4.3\%) and 10-methyl $\mathrm{C}_{17: 0}(7.0 \%)$ (Table 4).

On the basis of $16 \mathrm{~S}$ rRNA gene sequence and phylogenetic analysis (Figure 1), isolates AL8-8 (1506 nt) and AL10-3 (1501 nt) were closely related to $M$. aurantiaca JCM $10878^{\top}(99.7 \%), M_{\text {. }}$ marina JCM $12870^{\top}$ $(99.6 \%), M$. coxensis JCM $13248^{\top}(99.4 \%), M$. chalcea JCM $3031^{\top}(99.1 \%)$, and M. halophytica JCM $3125^{\top}$ (99.1\%). However, the DNA-DNA relatedness between isolates AL8-8 and AL 10-3 and M. aurantiaca JCM 10878 was $100-103 \%$. Therefore, they were identified as $M$. aurantiaca (Sveshnikova et al., 1969; Wayne et al., 1987).

Table 1: Sources, location, $\mathrm{pH}$, isolate number, group and identification of isolates.

\begin{tabular}{|c|c|c|c|c|c|}
\hline Sources & Location & $\mathrm{pH}$ & Isolate no. & Group & Identification \\
\hline Mountain soil & Phukradung, Loei & 7.00 & AL1-15-2, AL1-16B & $\mathrm{F}$ & M. chercina \\
\hline Mountain soil & Phukradung, Loei & 5.97 & AL3-16 & $\mathrm{D}$ & M. chokoriensis \\
\hline Mountain soil & Phukradung, Loei & 5.01 & $A L 7-5$ & C & M. chalcea \\
\hline Mountain soil & Phukradung, Loei & 9.66 & AL8-8 & B & M. aurantiaca \\
\hline Mountain soil & Phukradung, Loei & 6.49 & $\begin{array}{l}\text { AL9-20 } \\
\text { AL9-13, AL9-22 }\end{array}$ & $\begin{array}{l}D \\
E\end{array}$ & $\begin{array}{l}\text { M. chokoriensis } \\
\text { M. tulbaghiae }\end{array}$ \\
\hline Mountain soil & Phukradung, Loei & 5.02 & AL10-3 & B & M. aurantiaca \\
\hline Soil & Nok Island, Chonburi & 8.88 & ASC19-2-1 & $A$ & M. marina \\
\hline
\end{tabular}




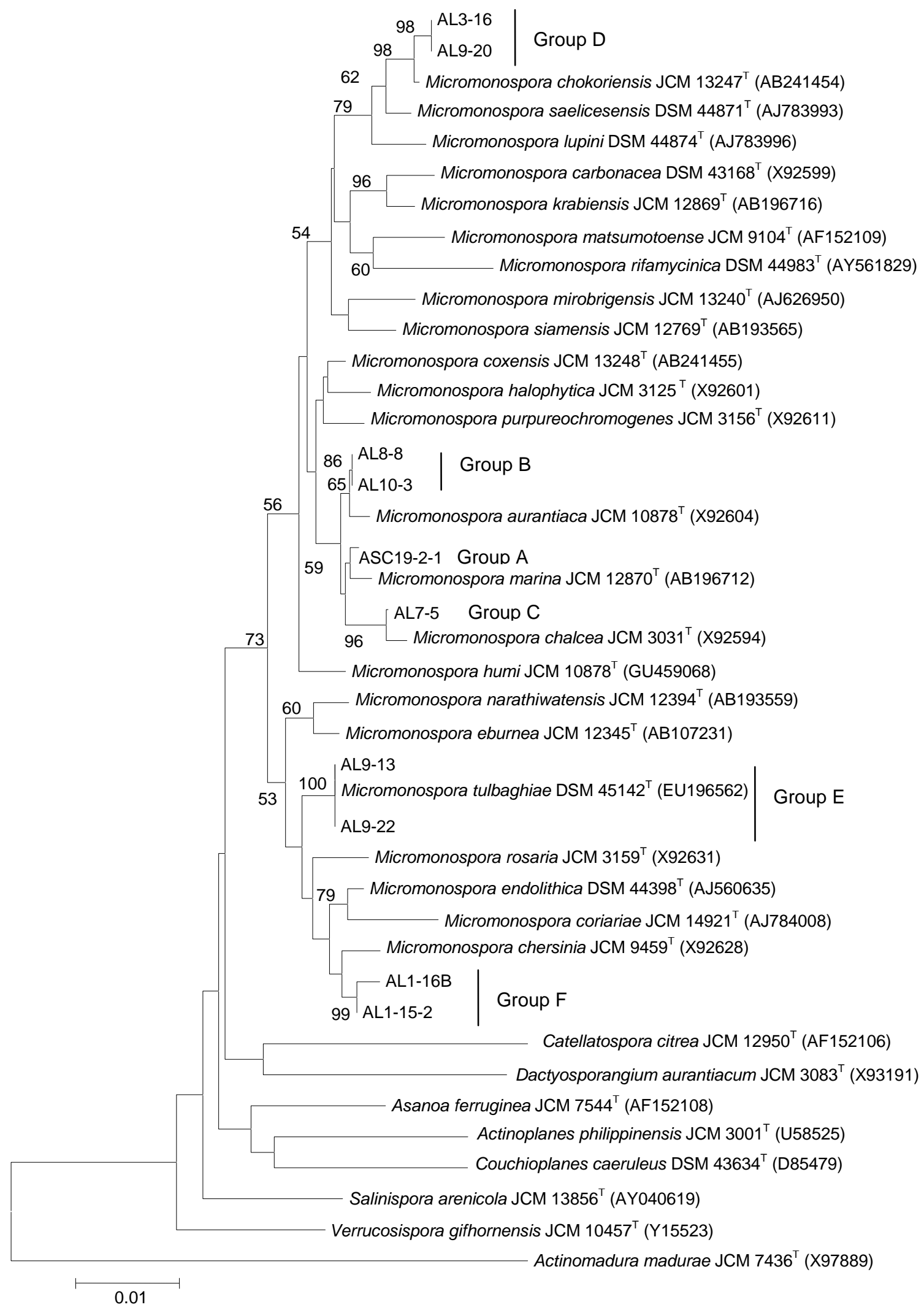

Figure 1: Neighbour-joining tree based on 16S rRNA gene sequences showing relationships among Micromonospora isolates and related Micromonospora species. The numbers on the branches indicate the percentage bootstrap values of 1,000 replicates; only values $>50 \%$ are indicated. Bar, 0.01 substitutions per nucleotide position. 
Table 2: Cultural characteristics of isolates on ISP 2 at $30^{\circ} \mathrm{C}$ for 14 days.

\begin{tabular}{llll}
\hline Group/ Isolate no. & & Yeast extract-malt extract agar (ISP 2) \\
\cline { 2 - 4 } A/ ASC19-2-1 & Growth & Colour of upper surface & Colour of reverse surface \\
B/ AL8-8 & Abundant & Brownish gray & Brownish gray \\
B/ AL10-3 & Abundant & Brownish black & Brownish black \\
C/ AL7-5 & Abundant & Brownish black & Dark brown \\
D/ AL3-16 & Abundant & Brownish black & Brownish black \\
D/ AL9-20 & Abundant & Deep orange yellow & Strong orange yellow \\
E/ AL9-13 & Abundant & Deep orange yellow & Strong orange yellow \\
E/ AL9-22 & Abundant & Black & Black \\
F/ AL1-15-2 & Abundant & Black & Black \\
F/ AL1-16B & Abundant & Black & Black \\
\hline
\end{tabular}

Group C contained isolate AL7-5. The isolate produced many rough singly spores on substrate hyphae (Figure 1). The colour of the vegetative mycelium was brownish black on ISP 2 (Table 2). This isolate grew on 1.5 to $4 \% \mathrm{NaCl}$, on $\mathrm{pH} 6$ to 8 and at 20 to $45{ }^{\circ} \mathrm{C}$. Peptonization and coagulation of milk, gelatin liquefaction, nitrate reduction and starch hydrolysis were positive. It utilized L-arabinose, cellobiose, D-galactose, D-glucose, glycerol, lactose, D-melibiose, raffinose, sucrose, Dxylose and D-fructose (weakly) but did not utilize inositol, D-mannitol, L-rhamnose, D-ribose and salicin (Table 3). Major menaquinones were MK-9 $\left(\mathrm{H}_{4}\right)(19.0 \%)$, MK-9 $\left(\mathrm{H}_{6}\right)$ $(6.6 \%), \mathrm{MK}-10\left(\mathrm{H}_{4}\right)(42.5 \%)$, MK-10 $\left(\mathrm{H}_{6}\right)(17.4 \%)$ and $\mathrm{MK}$ $10\left(\mathrm{H}_{8}\right)(2.9 \%)$. The major cellular fatty acids of isolate were iso- $\mathrm{C}_{15: 0}(13.8 \%)$ iso- $\mathrm{C}_{16: 0}(35.6 \%)$, iso- $\mathrm{C}_{17: 0}(9.2 \%)$, anteiso- $\mathrm{C}_{17: 0}(7.4 \%)$, iso- $\mathrm{C}_{17: 1 \omega 9 \mathrm{c}}(7.5 \%)$ (Table 4). On the basis of 16S rRNA gene sequence and phylogenetic analysis (Figure 1), isolate AL7-5 (1485 nt) was closely related to $M$. chalcea JCM $3031^{\top}(99.7 \%)$, M. marina JCM $12870^{\top}(99.3 \%)$, and $M$. aurantiaca JCM $10878^{\top}(99.1 \%)$. DNA-DNA relatedness between the strain and $M$. chalcea JCM $3031^{\top}$ was $92.6 \%$. Therefore, it was identified as $M$. chalcea (Wayne et al., 1987; Tanasupawat et al., 2010).

Group D contained 2 isolates, AL3-16 and AL9-20. Isolate AL9-20 produced smooth singly spores on substrate hyphae (Figure 2). The isolates produced deep orange yellow vegetative mycelium on ISP 2 (Table 2).
They grew on 1.5 to $5 \% \mathrm{NaCl}$, on $\mathrm{pH} 6$ to 8 and at 15 to $37^{\circ} \mathrm{C}$. Gelatin liquefaction and starch hydrolysis were positive but peptonization of milk and nitrate reduction were negative. They utilized L-arabinose, D-fructose, Dglucose, lactose, D-mannitol, raffinose, sucrose and Dmelibiose (weakly) but did not utilize cellobiose, Dgalactose, glycerol, inositol, L-rhamnose, D-ribose, salicin and D-xylose (Table 3). The isolates AL3-16 and AL9-20 contained major menaquinones $\mathrm{MK}-9\left(\mathrm{H}_{4}\right)(8.7,10.9 \%)$, MK-9 $\left(\mathrm{H}_{6}\right)(15.7,9.7 \%)$, MK-9 $\left(\mathrm{H}_{8}\right)(6.2,1.5 \%)$, MK-10 $\left(\mathrm{H}_{4}\right)$ $(12.7,30.7 \%)$, MK-10 $\left(\mathrm{H}_{6}\right)(33.3,32.1 \%)$, and MK-10 $\left(\mathrm{H}_{8}\right)$ $(23.4,12.2 \%)$. The isolate AL3-16 contained iso-C $15: 0$ $(30.5 \%)$, anteiso- $\mathrm{C}_{15: 0}(7.3 \%)$, anteiso- $\mathrm{C}_{17: 0}(10.9 \%)$, and iso- $\mathrm{C}_{17: 1 \omega 8 \mathrm{c}}(9.9 \%)$ as major cellular fatty acids (Table 4). Phylogenetic analysis using 16S rRNA gene sequences revealed that strains AL3-16 (1496 nt) and AL9-20 (1482 nt) were closely related to $M$. chokoriensis JCM $13247^{\top}$ $(99.8 \%)$ and $M$. saelicesensis JCM 44871 ${ }^{\top}(99.3 \%)$ (Figure 1). On the basis of phenotypic characteristics and 16S rRNA gene sequence similarity, these isolates were identified as M. chokoriensis (Ara and Kudo, 2007).

Group E contained 2 isolates, AL9-13 and AL9-22. Isolate AL9-13 produced rough singly spores on substrate hyphae (Figure 2). The isolates produced black vegetative mycelium on ISP 2 (Table 2). They grew on 1.5 to $4 \%$ $\mathrm{NaCl}$, at $\mathrm{pH} 5$ to 8 and at 15 to $45^{\circ} \mathrm{C}$. Milk peptonization, coagulation, gelatin liquefaction, nitrate reduction, and 


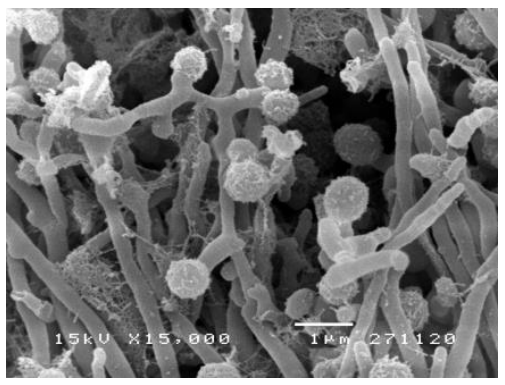

(1)

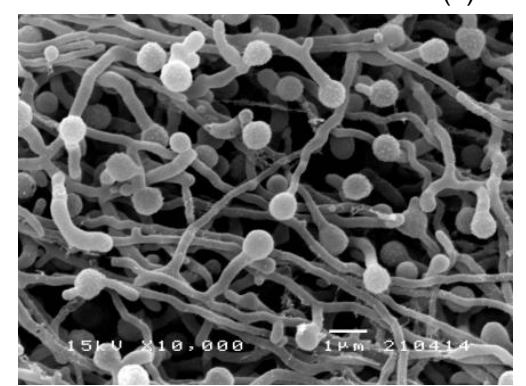

(4)

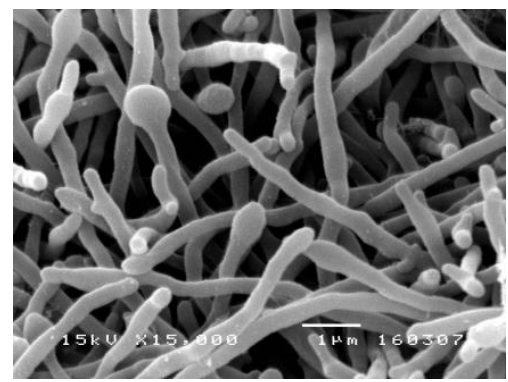

(2)

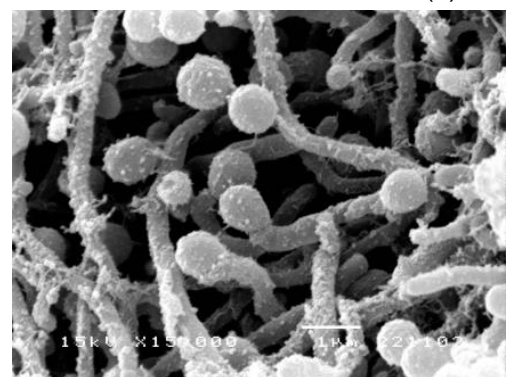

(5)

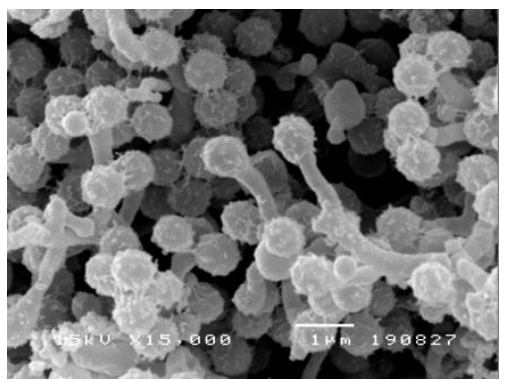

(3)

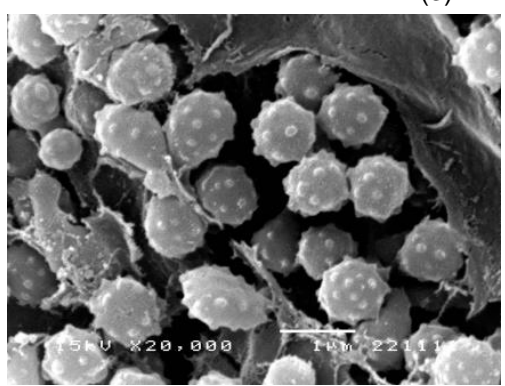

(6)

Figure 2: Scanning electron micrograph of Micromonospora isolates; 1, ASC19-2-1 (Group A); 2, AL10-3 (Group B); 3 , AL7-5 (Group C); 4, AL9-20 (Group D); 5, AL9-13 (Group E) and 6, AL1-15-2 (Group F) on ISP 2 agar medium incubated at $30^{\circ} \mathrm{C}$ for 14 days. Bar, $1 \mu \mathrm{m}$.

starch hydrolysis were positive. They utilized L-arabinose, cellobiose, D-fructose, D-glucose, salicin, sucrose and Dxylose and did weakly for D-galactose, glycerol and Lrhamnose (Table 3). The isolates AL9-13 and AL9-22 contained major menaquinones, MK-9 $\left(\mathrm{H}_{4}\right)(8.0,11.8 \%)$ MK-10 $\left(\mathrm{H}_{4}\right)(48.2,72.7 \%)$, and MK-10 $\left(\mathrm{H}_{6}\right)(25.0,7.4 \%)$. Major cellular fatty acids of AL9-22 were iso- $\mathrm{C}_{16: 0}(14.9 \%)$, iso- $\mathrm{C}_{15: 0}(20.7 \%)$, anteiso- $\mathrm{C}_{17: 0}(12.1 \%)$, iso- $\mathrm{C}_{17: 0}(10.7 \%)$ and $\mathrm{C}_{17: 1 \omega 8 \mathrm{c}}(7.1 \%)$ (Table 4). Phylogenetic analysis using 16S rRNA gene sequences revealed that isolates AL9-13 (1460 nt) and AL9-20 (1482 nt) showed 100\% similarity with $M$. tulbaghiae DSM $45142^{\top}$ (Figure 2). Therefore, they were identified as M. tulbaghiae (Kirby and Meyers, 2010).

Group F contained 2 isolates, AL1-15-2 and AL1-16B. Isolate AL1-15-2 produced warty spores on the substrate hyphae (Figure 2) and the vegetative mycelium color was black (Table 2). They grew on 1.5 to $3 \% \mathrm{NaCl}$, on $\mathrm{pH} 5$ to 8 and at 20 to $37^{\circ} \mathrm{C}$. Milk peptonization, nitrate reduction and starch hydrolysis were negative but gelatin liquefaction was positive (Table 2). They utilized Larabinose, cellobiose, D-galactose, D-glucose, raffinose, salicin, sucrose and D-xylose as sole carbon sources but not D-fructose, inositol, lactose, D-mannitol, D-melibiose and D-ribose (Table 3). The isolates AL1-15-2 and AL1$16 \mathrm{~B}$ contained major menaquinones, MK-9 $\left(\mathrm{H}_{4}\right)$ (6.6, $14.2 \%)$, MK-9 $\left(\mathrm{H}_{6}\right)(22.2,30.6 \%)$, MK-9 $\left(\mathrm{H}_{8}\right)(5.0,14.5 \%)$, MK-10 $\left(\mathrm{H}_{4}\right)(9.4,6.8 \%)$, MK-10 $\left(\mathrm{H}_{6}\right)(40.3,20.2 \%)$ and MK$10\left(\mathrm{H}_{8}\right)(14.6,13.6 \%)$. The major cellular fatty acids of AL1-15-2 were iso- $\mathrm{C}_{16: 0}(13.9 \%)$, iso- $\mathrm{C}_{15: 0}(28.3 \%)$, anteiso- $\mathrm{C}_{17: 0}(6.5 \%)$, iso- $\mathrm{C}_{17: 0}(13.0 \%), \mathrm{C}_{17: 0}(6.3 \%), \mathrm{C}_{18: 0}$ (5.1\%), iso- $C_{17: 1 \omega 9 c}(7.2 \%)$, and $C_{17: 1 \omega 8 c}(5.2 \%)$ (Table 4).
Phylogenetic analysis using 16S rRNA gene sequences revealed that strains AL1-15-2 (1479 nt) and AL1-16B (1505 nt) were closely related to $M$. chersina JCM 9459 ${ }^{\top}(99.5,99.4 \%), M$. rosaria JCM $3159^{\top}$ (99.3, $99.2 \%$ ) and $M$. endolithica JCM $12677^{\top}$ (99.1, 99.1\%) (Figure 1). The DNA G+C content of isolates, AL1-15-2 and $A L 1-16 B$ were 72.1 and $72.0 \mathrm{~mol} \%$, respectively. The levels of DNA-DNA relatedness between strain AL1-15-2 and $\mathrm{AL} 1-16 \mathrm{~B}$ and $M$. chersina $\mathrm{JCM} 9459^{\top}$, the closest related species were 87.8 and $78.4 \%$, respectively. Therefore, isolates AL1-15-2 and AL1-16B were identified as M. chersina (Wayne et al., 1987; Tomita et al., 1992).

\section{Screening of antimicrobial activities and preliminary characterization of secondary metabolites}

The results of primary screening on agar plates revealed that the nine isolates showed no antimicrobial activities against the test microorganisms mentioned above except the isolate AL7-5 that could inhibit Kocuria rhizophila ATCC 9341. The representative isolates of each group, ASC19-2-1, AL10-3, AL7-5, AL9-20, AL9-13 and AL1-15-2 were further cultivated in $\mathrm{A} 3 \mathrm{M}, \mathrm{A} 11 \mathrm{M}$ and $\mathrm{A} 16$ broth. The fermentation broth was extracted for preliminary characterization of secondary metabolites. We found that only isolate AL7-5 which was identified as $M$. chalcea could produce rakicidin (McBrien et al., 1995) (Figure 3a) when cultivated on $\mathrm{A} 3 \mathrm{M}, \mathrm{A} 11 \mathrm{M}$ and $\mathrm{A} 16$ and produced compound BU4664L (Figure $3 \mathrm{~b}$ ) only on A16 (Igarashi et al., 2005). 

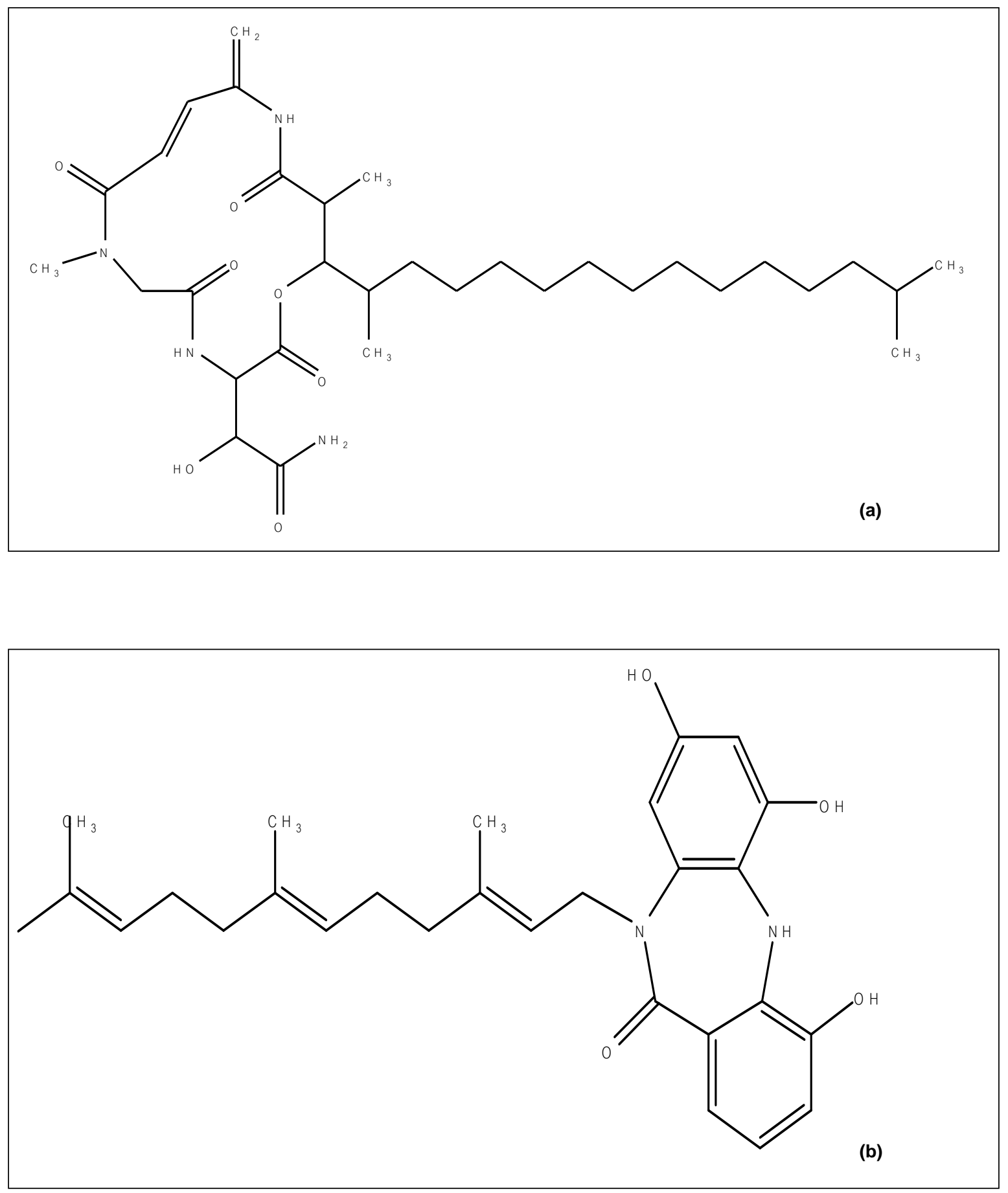

Figure 3: The structure of rakicidin (a) and BU4664L (b). 
Mal. J. Microbiol. Vol 9(3) 2013, pp. 260-270

Table 3: Differential characteristics of isolates in Group A, B, C, D, E, F and closely related Micromonospora species.

\begin{tabular}{|c|c|c|c|c|c|c|c|c|c|c|c|c|}
\hline Characteristics & 1 & 2 & 3 & 4 & 5 & 6 & 7 & 8 & 9 & $10^{a}$ & 11 & 12 \\
\hline Max. $\mathrm{NaCl}(\%, w / v)$ & 5 & 5 & 5 & 3 & 4 & 3 & 5 & 5 & 4 & 5 & 3 & 4 \\
\hline Growth at pH 5 & + & + & + & + & - & - & - & - & + & - & + & - \\
\hline Growth at $40^{\circ} \mathrm{C}$ & + & + & + & + & + & + & - & - & + & - & - & + \\
\hline Growth at $45^{\circ} \mathrm{C}$ & - & + & - & + & + & - & - & - & + & - & - & + \\
\hline Peptonization of milk & + & - & + & + & + & - & - & - & + & nd & - & + \\
\hline Gelatin liquefaction & + & + & + & + & + & + & + & + & + & + & + & + \\
\hline Nitrate reduction & - & - & + & + & + & - & - & - & + & - & - & + \\
\hline Starch hydrolysis & + & + & + & + & + & + & + & + & + & + & - & + \\
\hline \multicolumn{13}{|l|}{ Utilization of: } \\
\hline L-Arabinose & + & - & + & + & + & w & + & + & + & - & + & - \\
\hline Cellobiose & + & + & + & + & + & + & - & - & + & - & + & + \\
\hline D-Fructose & w & - & + & + & w & - & + & + & + & + & - & w \\
\hline D-Galactose & + & + & + & + & + & + & - & - & w & nd & + & + \\
\hline D-Glucose & + & + & + & + & + & + & + & + & + & + & + & + \\
\hline Glycerol & + & + & $w(+1)$ & + & + & + & - & - & w & - & $+(-1)$ & - \\
\hline Inositol & - & - & + & - & - & - & - & - & - & + & - & - \\
\hline Lactose & w & - & $+(-1)$ & w & + & + & + & + & - & - & - & + \\
\hline D-Mannitol & - & - & - & - & - & w & + & + & - & + & - & - \\
\hline D-Melibiose & - & - & - & - & + & + & w & w & - & - & - & + \\
\hline Raffinose & - & - & + & - & + & + & + & + & - & - & + & + \\
\hline L-Rhamnose & - & - & - & - & - & - & - & w & w & + & $+(-1)$ & - \\
\hline D-Ribose & - & - & - & - & - & - & - & - & - & + & - & - \\
\hline Salicin & + & + & $w(-1)$ & + & - & + & - & - & + & - & + & - \\
\hline Sucrose & w & - & + & - & + & - & + & + & + & nd & + & + \\
\hline D-Xylose & w & - & + & - & + & - & - & - & + & - & + & nd \\
\hline
\end{tabular}

1, Group A (1 isolate); 2, M. marina JCM $12870^{\top} ; 3$, Group B (2 isolates); 4, M. aurantiaca JCM 10878 ${ }^{\top} ; 5$, Group C; 6, M. chalcea JCM 3031 ${ }^{\top}$; 7, Group D (2 isolates); 8, M. chokoriensis JCM 13247 ${ }^{\top}$; 9 , Group E (2 isolates); 10, M. tulbaghiae DSM 45142 ${ }^{\top}$;

11 , Group F (2 isolates); $12, M$. chersina JCM $9459^{\top}$. nd, no data. Number in parentheses indicates the number of isolate shows positive or negative reaction. ${ }^{a}$ Data from Kirby and Meyers (2010). 
Table 4: Cellular fatty acid profiles of isolates.

\begin{tabular}{|c|c|c|c|c|c|c|}
\hline 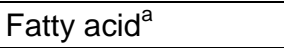 & 1 & 2 & 3 & 4 & 5 & 6 \\
\hline \multicolumn{7}{|l|}{ Saturated fatty acids } \\
\hline $\mathrm{C}_{15: 0}$ & $\operatorname{tr}$ & $\operatorname{tr}$ & $\operatorname{tr}$ & 1.7 & 0.6 & 0.5 \\
\hline $\mathrm{C}_{16: 0}$ & 0.8 & $\operatorname{tr}$ & 0.9 & 3.2 & 0.7 & 3.5 \\
\hline $\mathrm{C}_{17: 0}$ & 2.8 & 1.1 & 1.1 & 7.8 & 4.7 & 6.3 \\
\hline $\mathrm{C}_{18: 0}$ & 1.7 & 1.3 & 3.0 & 2.0 & 1.3 & 5.1 \\
\hline \multicolumn{7}{|c|}{ Unsaturated fatty acids } \\
\hline $\mathrm{C}_{17: 1} \omega 8 \mathrm{c}$ & 6.4 & 2.6 & 2.3 & 7.9 & 7.1 & 5.2 \\
\hline $\mathrm{C}_{18: 1} \omega 9 \mathrm{c}$ & 3.4 & 4.3 & 5.4 & 4.2 & 3.2 & 1.0 \\
\hline \multicolumn{7}{|l|}{ Branched fatty acids } \\
\hline iso- $\mathrm{C}_{14: 0}$ & $\operatorname{tr}$ & 0.9 & 0.6 & $\operatorname{tr}$ & $\operatorname{tr}$ & 0.7 \\
\hline iso- $\mathrm{C}_{15: 0}$ & 18.5 & 6.4 & 13.8 & 30.5 & 20.7 & 28.3 \\
\hline anteiso- $\mathrm{C}_{15: 0}$ & 6.1 & 3.0 & 2.6 & 5.4 & nd & 3.6 \\
\hline iso- $\mathrm{C}_{16: 1}$ & 0.7 & 1.2 & 0.6 & $\operatorname{tr}$ & $\operatorname{tr}$ & 0.6 \\
\hline iso- $\mathrm{C}_{16: 0}$ & 20.1 & 42.5 & 35.6 & 4.0 & 14.9 & 13.9 \\
\hline iso- $\mathrm{C}_{17: 1} \omega 9 \mathrm{c}$ & 8.3 & 6.2 & 7.5 & 4.4 & 6.8 & 7.2 \\
\hline anteiso- $\mathrm{C}_{17: 1} \omega 9 \mathrm{c}$ & 1.1 & 1.1 & $\operatorname{tr}$ & 0.6 & 0.6 & 0.8 \\
\hline iso- $\mathrm{C}_{17: 0}$ & 10.0 & 4.1 & 9.2 & 6.1 & 10.7 & 13.0 \\
\hline iso- $\mathrm{C}_{18: 0}$ & 0.9 & 3.4 & 2.8 & nd & 0.7 & 0.5 \\
\hline anteiso- $\mathrm{C}_{17: 0}$ & 13.2 & 11.4 & 7.4 & 8.2 & 12.1 & 6.5 \\
\hline \multicolumn{7}{|c|}{ 10-Methylated fatty acids } \\
\hline 10-Methyl $C_{17: 0}$ & 1.8 & 7.0 & 2.6 & 7.3 & 4.3 & 1.1 \\
\hline 10-Methyl $C_{18: 0}$ & 0.5 & 0.8 & 1.6 & 3.0 & 1.5 & $\operatorname{tr}$ \\
\hline Summed feature $3^{b}$ & 0.9 & $\operatorname{tr}$ & 0.7 & $\operatorname{tr}$ & $\operatorname{tr}$ & $\operatorname{tr}$ \\
\hline Summed feature $6^{\mathrm{C}}$ & 0.5 & $\operatorname{tr}$ & $\operatorname{tr}$ & 0.7 & 0.9 & tr \\
\hline
\end{tabular}

1, ASC19-2-1; 2, AL8-8; 3, AL7-5; 4, AL3-16; 5, AL9-22 ; 6, AL1-15-2. nd, not detected. ${ }^{a}$ Values are percentages of total fatty acids. ${ }^{b}$ Summed feature 3 contains $C_{16: 1} \omega 7 \mathrm{c} / C_{15: 0}$ iso $2-O H$. ${ }^{c}$ Summed feature 6 contains $C_{19: 1} \omega 11 \mathrm{c} / C_{19: 1 \omega 9}$ c. tr, trace less than $0.5 \%$.

\section{CONCLUSION}

Nine rare actinomycete strains from the genus Micromonospora were isolated from mountain soils in Phukradung, Loei province, the north eastern part of Thailand and they were identified as $M$. aurantiaca, $M$. chalcea, M. chokoriensis and M. chersina. One isolate from Nok Island, Chonburi province, the eastern part of Thailand was identified as M. marina. They were identified based on morphological, cultural, physiological and biochemical characteristics including chemotaxonomic characteristics, DNA-DNA relatedness and 16S rRNA gene analyses. Only $M$. chalcea AL7-5 could produce rakicidin and compound BU4664L and showed antibacterial activity against $K$. rhizophila ATCC 9341.

\section{ACKNOWLEDGEMENT}

This study was supported by the Thailand Research Fund for a 2006 Royal Golden Jubilee Ph.D. Program as a scholarship to A.S.

\section{REFERENCES}

Ara, I. and Kudo, T. (2007). Two new species of the genus Micromonospora: Micromonospora chokoriensis sp. nov. and Micromonospora coxensis sp. nov., isolated from sandy soil. Journal of General and Applied Microbiology 53, 29-37.

Arai, T. (1975). Culture Media for Actinomycetes. The Society for Actinomycetes Japan, Tokyo. pp. 1-31.

Berdy, J. (2005). Bioactive microbial metabolites: Review article. Journal of Antibiotics 58, 1-26.

Collins, M. D., Pirouz, T., Goodfellow, M. and Minnikin, D. E. (1977). Distribution of menaquinones in Actinomycetes and Corynebacteria. Journal of General Microbiology 100, 221-230.

Ezaki, T., Hashimoto, Y. and Yabuuchi, E. (1989). Fluorometric deoxyribonucleic acid-deoxyribonucleic acid hybridization in microdilution wells as an alternative to membrane filter hybridization in which radioisotopes are used to determine genetic 
relatedness among bacterial strains. International Journal of Systematic Bacteriology 39, 224-229.

Felsenstein, J. (1985). Confidence limits on phylogenies: An approach using the bootstrap. Evolution 39, 783791.

Garcia, L. C., Martínez-Molina, E. and Trujillo, M. E. (2010). Micromonospora pisi sp. nov., isolated from root nodules of Pisum sativum. International Journal of Systematic and Evolutionary Microbiology 60, 331337.

Glasby, S. J. (1993). Encyclopedia of Antibiotics. $3^{\text {rd }}$ Edn. John Wiley \& Sons, London. pp. 1-712.

Goodfellow, M., Stanton, L. J., Simpson, K. E. and Minnikin, D. E. (1990). Numerical and chemical classification of Actinoplanes and some related Actinomycetes. Journal of General Microbiology 136, 19-36.

Gordon, R. E., Barnett, D. A., Handerhan, J. E. and Pang, C. H-N. (1974). Nocardia coeliaca, Nocardia autotrophica, and the nocardin strain. International Journal of Systematic Bacteriology 24, 54-63.

Hirsch, P., Mevs, U., Kroppenstedt, R. M., Schumann, P. and Stackebrandt, E. (2004). Crytoendolithic actinomycetes from Antarctic sandstone rock samples: Micromonospora endolithica sp. nov. and two isolates related to Micromonospora coerulea Jensen 1932. Systematic and Applied Microbiology 27, 166-174.

Igarashi, Y., Takagi, K., Kan, Y., Fujii, K., Harada, K. I., Furumai, T. and Oki. T. (2000). Arisostatins A and B, new members of tetrocardin class of antibiotics from Micromonospora sp. TP-A0316. Journal of Antibiotics 53, 233-240.

Igarashi, Y., Miyanaga, S., Onaka, H., Takeshita, M. and Furumai, T. (2005). Revision of the structure assigned to the antibiotic BU-4664L from Micromonopora. Journal of Antibiotics 58, 350-352.

Igarashi, Y., Trujillo, M. E., Martinez-Molina, E., Yanase, S., Miyanaga, S., Obata, T., Sakurai, H., Saiki, I., Fujita, T. and Furumai, T. (2007). Antitumor anthraquinones from an endophytic actinomycete Micromonospora lipini sp. nov. Bioorganic \& Medicinal Chemistry Letters 17, 3702-3705.

Kämpfer, P. and Kroppenstedt, R. M. (1996). Numerical analysis of fatty acid patterns of coryneform bacteria and related taxa. Canadian Journal of Microbiology 42, 989-1005.

Kasai, H., Tamura, T. and Harayama, S. (2000). Intrageneric relationships among Micromonospora species deduced from gyrB-based phylogeny and DNA relatedness. International Journal of Systematic Bacteriology 50, 127-134.

Kawamoto, I. (1989). Genus Micromonospora Ørskov 1923, 147 ${ }^{\mathrm{AL}}$. In: Bergey's Manual of Systematic Bacteriology. Williams, S. T., Sharpe, M. E. and Holt, J. G. (eds.). vol. 4. Williams and Wilkins, Baltimore. pp. 2442-2450.

Kawamoto, I., Oka, T. and Nara, T. (1981). Cell wall composition of Micromonospora olivasterospora,
Micromonospora sagamiensis, and related organisms. Journal of Bacteriology 146, 527-534.

Koch, C., Kroppentedt, R. M. and Stackebrandt, E. (1996). Intrageneric relationships of the actinomycete genus Micromonospora. International Journal of Systematic Bacteriology 46. 383-387.

Kirby, B. M. and Meyers, P. R. (2010). Micromonospora tulbaghiae sp. nov., isolated from the leaves of wild garlic, Tulbaghia violacea. International Journal of Systematic and Evolutionary Microbiology 60, 13281333.

Lechevalier, M. P. and Lechevalier, H. (1970). Chemical composition as a criterion in the classification of aerobic actinomycetes. International Journal of Systematic Bacteriology 48, 1245-1255.

Luedemann, G. M. and Brodsky, B. C. (1964). Micromonospora carbonacea sp. nov., an everninomicin-producing organism. Antimicrobial Agents and Chemotherapy 10, 47-52.

MacBrien, K. D., Berry, R. L., Lowe, S. E., Neddermann, K. M., Bursuker, I., Huang, S., Klohr, S. E. and Leet, J. E. (1995). Rakicidins, new cytotoxic lipopeptides from Micromonospora sp. fermentation, isolation and characterization. Journal of Antibiotics 48, 1446-1452.

Mikami, H. and Ishida, Y. (1983). Post-column fluorometric detection of reducing sugars in high performance liquid chromatography using arginine. Bunseki Kagaku 32, E-207-E210.

Nakajima, Y., Kitpreechavanich, V., Suzuki, K. and Kudo, T. (1999). Microbispora corallina sp. nov., a new species of the genus Microbispora isolated from Thai soil. International Journal of Systematic Bacteriology 49, 1761-1767.

Omura, S. (2008). Splendid gift from microorgainisms-The achievements of Satoshi Omura and Collaborators, 4th Edn., Kitasato Institute for Life Sciences, Kitasato University. pp. 1-420.

Saitou, N. and Nei, M. (1987). The neighbor-joining method: A new method for reconstructing phylogenetic trees. Molecular Biology and Evolution 4, 406-425.

Sasser, M. (1990). Identification of bacteria by gas chromatography of cellular fatty acids. USFCC News/ 20: 1-6.

Shirling, E. B. and Gottlieb, D. (1966). Methods for characterization of Streptomyces species. International Journal of Systematic Bacteriology 16, 313-340.

Staneck, J. L. and Roberts, G. D. (1974). Simplified approach to identification of aerobic actinomycetes by thin-layer chromatography. Journal of Applied Microbiology 28, 226-231.

Songsumanus, A., Tanasupawat, S., Thawai, C., Suwanborirux, K. and Kudo, T. (2011). Micromonospora humi sp. nov., isolated from Thai peat swamp forest soil. International Journal of Systematic and Evolutionary Microbiology 61, 1176-1181.

Sveshnikova, M. A., Maksimova, T. S. and Kudrina, E. S. (1969). The species of the Micromonospora 
Ørskov, 1923, and their taxonomy. Mikrobiologiya 38, 883-893. (Russian).

Tamaoka, J. (1994). Determination of DNA base composition. In: Chemical Methods in Prokaryotic Systematics, Goodfellow, M. and O'Donnel, A. G. (eds.). John Wiley \& Son Ltd, Chichester. pp. 463470.

Tanasupawat, S., Jongrungruangchok, S. and Kudo, T. (2010). Micromonospora marina sp. nov., isolated from sea sand. International Journal of Systematic and Evolutionary Microbiology 60, 648-652.

Thompson, J. D., Gibson, T. J., Plewniak, F., Jeanmougin, F. and Higgins, D. G. (1997). CLUSTAL_X windows interface: Flexible strategies for multiple sequence alignment aided by quality analysis tools. Nucleic Acids Research 25, 48764882.

Tomita, K., Hoshino, Y., Ohkusa, N., Tsuno, T. and Miyaki, T. (1992). Micromonospora chersina sp. nov. Actinomycetologica 6, 21-28.

Uchida, K. and Aida, K. (1984). An improved method for the glycolate test for simple identification of the acyl type of bacterial cell walls. Journal of General and Applied Microbiology 30, 131-134.

Wang, C., Xu, X. -X., Qu, Z., Wang, H. -L., Lin, H. -P., Xie, Q. -Y., Ruan, J. -S. and Hong, K. (2011). Micromonospora rhizosphaerae sp. nov., isolated from mangrove rhizosphere soil. International Journal of Systematic and Evolutionary Microbiology 61, 320324.

Wayne, L. G., Brenner, D. J., Colwell, R. R., Grimont, P. A. D., Kandler, O., Krichevsky, M. I., Moore, L. H., Moore, W. E. C., Murray, R. G. E., Stackebrandt, E., Starr, M. P. and Trüper, H. G. (1987). International Committee on Systematic Bacteriology. Report of the Ad Hoc committee on the reconciliation of approaches to bacterial systematics. International Journal of Systematic Bacteriology 37, 463-464.

Williams, S. T. and Cross, T. (1971). Actinomycetes. Methods in Microbiology 4, 295-334.

Yamada, K. and Komagata, K. (1970). Taxonomic studies on coryneform bacteria. III. DNA base composition of coryneform bacteria. Journal of General and Applied Microbiology 16, 215-224. 